\title{
Tillage Effects on Macrophomina phaseolina Population Density and Soybean Yield
}

\author{
J. A. Wrather and S. R. Kendig, University of Missouri-Delta Center, P. O. Box 160, Portageville 63873; and \\ D. D. Tyler, University of Tennessee-Jackson, 605 Airways Blvd., Jackson 38301
}

\begin{abstract}
Wrather, J. A., Kendig, S. R., and Tyler, D. D. 1998. Tillage effects on Macrophomina phaseolina population density and soybean yield. Plant Dis. 82:247-250.

Reduced-tillage production systems have become popular with soybean farmers in the United States. During 1992 to 1994, soil and soybean root samples were collected from disk-tillage, notillage, and moldboard plow treatments in an experiment conducted since 1979 at the University of Tennessee in Jackson. The objective was to determine if reduced-tillage production systems affected charcoal rot incidence and severity. There were no differences at planting in soil population density of Macrophomina phaseolina in the 0- to 15-cm layer of soil among treatments. However, the soil population density of $M$. phaseolina in disk-tillage and no-tillage plots was significantly greater in the 0 - to $7.5-\mathrm{cm}$ layer of soil than in the $7.5-$ to $15-\mathrm{cm}$ layer. Similarly, soil population densities were significantly greater in the $0-$ to $7.5-\mathrm{cm}$ layer of soil in no-tillage than in either disk-tillage or moldboard plowed plots. Tillage did not affect the number of $M$. phaseolina infection sites in 6-week-old plant roots or the percentage of root segments of physiologically mature plants colonized by $M$. phaseolina. There was no significant correlation between soybean yield and $M$. phaseolina soil population density. These data suggest that longterm tillage did not affect charcoal rot incidence and severity.
\end{abstract}

Charcoal rot, caused by Macrophomina phaseolina (Tassi) Goidanich, is a serious problem of soybean, Glycine max (L.) Merr. (23). For example, the estimated total yield loss due to this disease in Argentina, Brazil, Canada, Paraguay, and the United States during 1994 was 1.23 million metric tons, valued at $\$ 272.26$ million (\$220.50/metric ton) (21). In the United States alone, the yield loss attributable to charcoal rot in 1994 was 0.28 million metric tons, valued at $\$ 60.65$ million.

There are few strategies for control of charcoal rot in soybean. There are no resistant genotypes, although the rates of pathogen colonization may differ among soybean cultivars (11). Crop rotation is of limited benefit as a control tactic for charcoal rot because this fungus has a wide host range (8). However, lower soil population densities of $M$. phaseolina occur as soybeans are grown less frequently in rotation with either corn or cotton in southeast Missouri (3). Moreover, cotton in

Corresponding author: J. A. Wrather

E-mail: wratherj@ext.missouri.edu

Published as Journal Series 12,691 of the University of Missouri Agriculture Experiment Station.

This research was supported by Missouri Soybean Merchandising Council grant 089 and USDA CSRS grant 93-34113-8498.

Accepted for publication 10 November 1997.

Publication no. D-1997-1215-02R

(C) 1998 The American Phytopathological Society rotation with soybean consistently reduced the population density of $M$. phaseolina more than did corn-soybean rotations. These results suggest that only long-term rotations of soybean with cotton or corn would be effective in decreasing the population density of $M$. phaseolina to nondamaging levels. Alternative methods are needed to reduce the density of this fungus in soil.

The soil population density of $M$. phaseolina can be affected by tillage. Rothrock and Hargrove (13) determined that the population density of this fungus in the upper $15-\mathrm{cm}$ layer of soil was significantly greater under grain sorghum rows in notillage than in moldboard plow plots 4 years after the tillage treatments were established.

The effect of tillage systems on soybean diseases is important because there is a trend toward reduced-tillage production systems in the United States (6). Tillage before planting a full-season soybean crop can affect the incidence of brown spot (19), stem canker $(14,19)$, and sudden death syndrome (22). In addition, tillage just prior to planting soybean after harvest of winter wheat affected the incidence of brown spot and bacterial blight (20). The population dynamics of soilborne pests such as soybean cyst nematode $(1,17)$ and Rhizoctonia spp. (12) can also be affected by tillage.

The objective of this project was to determine if tillage treatments affected soybean yields and soil and soybean root population densities of $M$. phaseolina.
Data were collected during 1992 to 1994 from long-term tillage plots established in 1979 at the University of Tennessee in Jackson. Charcoal rot symptoms had been observed previously on some plants scattered through the test site, but no yield loss was attributed to this disease.

\section{MATERIALS AND METHODS}

A long-term tillage experiment involving continuous soybean was initiated in 1979 at the University of Tennessee at Jackson on a Lexington silt loam soil (finesilty, mixed, thermic Typic Paleudalf). Treatments were no-tillage, moldboard plow ( $0.25 \mathrm{~m}$ deep) followed by disking, and disking alone (0.1 $\mathrm{m}$ deep). Each year, plots were tilled just prior to planting soybeans in late May. Vegetation in all plots was chemically killed with paraquat (Zeneca Ag. Products, Wilmington, DE) at $0.71 \mathrm{~kg} / \mathrm{ha}$ about 3 weeks prior to soybean planting. Residual weed control in all soybean plots was accomplished by preemergence application of alachlor (Monsanto Company, St. Louis, MO) at $3.36 \mathrm{~kg} / \mathrm{ha}$ and metribuzin (Miles Inc., Kansas City, MO) at $0.42 \mathrm{~kg} / \mathrm{ha}$. All plots were treated with alachlor, metribuzin, and paraquat, and all treatments except no-tillage were cultivated for supplemental weed control.

The tillage treatments were replicated four times in a randomized complete block design. Each plot was $6 \mathrm{~m}$ wide and $18 \mathrm{~m}$ long. From 1979 to 1982 , the soybean cv. Forrest was planted in six rows (1-m spacing) per plot. From 1983 to 1984, four rows each of the soybean cvs. Bedford and Forrest (0.75-m spacing) were planted in each plot. During 1984 to 1991 , eight rows of cv. Hutcheson (0.75-m spacing) were planted per plot, and cv. TN 4-86 was planted from 1992 to 1994 . The middle two rows of each plot were harvested at maturity by combine, and yield was adjusted to $13 \%$ moisture.

Charcoal rot symptoms were not observed on the aboveground portions of plants in this experiment during 1992 to 1994. So charcoal rot disease data were not collected.

During 1992 to 1994, soybean plots were sampled for soil population density of M. phaseolina at planting. In 1992, four sets of soil cores were collected from each plot. The four sets consisted of 10 soil cores collected from within the two center rows and 10 from between the two center rows of each plot, and each core $(2.5 \mathrm{~cm}$ 
diameter $\times 15 \mathrm{~cm}$ deep) was separated at collection into two portions by depth, 0 to $7.5 \mathrm{~cm}$ and 7.5 to $15 \mathrm{~cm}$. The cores were bulked by depth and by location relative to the row and analyzed for microsclerotia of M. phaseolina. Soil cores were collected at planting in 1993 as in 1992, except cores were not bulked by depth or location relative to the row but were analyzed separately. No significant differences were observed in the population density of this fungus within individual plots of any treatment in 1993, so the 1993 subsample means were used in further analysis. There were no significant differences in $M$. phaseolina population density between the in-row and between-row samples during 1992 and 1993. Consequently, the 1994 soil samples collected from each plot were a composite of 10 cores collected from within and between rows (5 cores from each location), and these were separated at collection into two portions by depth, 0 to $7.5 \mathrm{~cm}$ and 7.5 to $15 \mathrm{~cm}$.

Microsclerotial soil estimates were made by a modification of the procedure described by Short et al. (15). Soil samples were air-dried and then passed through a 45- $\mu \mathrm{m}$-mesh sieve. A 5 -g portion of the sieved soil was suspended in a 500-ml flask containing $250 \mathrm{ml}$ of $0.5 \%$ sodium hypochlorite. The flask containing the suspension was placed on a rotating shaker (120 cycles per min) for $10 \mathrm{~min}$. The suspension was then poured onto a $325-\mu \mathrm{m}-$ mesh sieve, and the debris was rinsed with tap water for $30 \mathrm{~s}$. The residue on the sieve was transferred to a 250-ml flask, and 100 $\mathrm{ml}$ of the selective medium CholornebMercury-Rose Bengal agar (CMRB) was added (7). The suspension was gently swirled and then divided among five petri plates. The petri plates were incubated in the dark at $33^{\circ} \mathrm{C}$ for 5 to 7 days. Microsclerotia densities were calculated from the number of colony-forming units on the plates and adjusted to a per gram of airdried soil basis. The colonies were identified as a ring of fluffy white mycelium surrounding a central area with black sclerotia.

Early season root infection by $M$. phaseolina was investigated during 1993 and 1994. Ten arbitrarily selected plants, V6 growth stage (2), were removed from the outside two rows of each plot. The intact roots were surface disinfested in $0.5 \%$ sodium hypochlorite for $60 \mathrm{~s}$ and then placed on a thin layer of CMRB agar in large trays $(22.5 \times 45 \mathrm{~cm})$. CMRB agar, $50^{\circ} \mathrm{C}$, was then poured over the top of the root system, and the tray was covered to prevent drying of the medium and contamination. Roots were incubated at $32^{\circ} \mathrm{C}$ for 5 days, and the number of colonies of M. phaseolina was then recorded. Each colony was considered an infection site on roots. The number of colonies developing on roots 0 to $7.5 \mathrm{~cm}$ from the hypocotylroot transition zone was kept separate from the number on roots 7.5 to $15 \mathrm{~cm}$ from this zone. The numbers of colonies on roots 0 to $7.5 \mathrm{~cm}$ or 7.5 to $15 \mathrm{~cm}$ from this transition zone are hereafter referred to as infec-

Table 1. Analysis of variance for soil population density of Macrophomina phaseolina and for the number of M. phaseolina infection sites on roots of V6 growth stage plants for year, tillage, and soil depth $^{\mathrm{a}}$

\begin{tabular}{lccccc}
\hline & \multicolumn{2}{c}{ Soil population density } & & \multicolumn{2}{c}{ Infection sites on plant roots (no.) } \\
\cline { 2 - 3 } \cline { 5 - 6 } Source of variation & $\mathbf{d f}$ & Mean square $^{\mathbf{b}}$ & & $\mathbf{d f}$ & Mean square $^{\mathbf{b}}$ \\
\hline Year (Y) & 2 & $0.157^{*}$ & & 1 & $10,980.75^{* *}$ \\
Rep & 3 & 0.026 & & 3 & 303.98 \\
Error A & 6 & 0.031 & & 3 & 330.15 \\
Tillage (T) & 2 & 0.017 & & 2 & 589.15 \\
Y $\times$ T & 4 & 0.038 & & 2 & 57.56 \\
Error B & 1 & 0.017 & & 12 & 752.27 \\
Depth (D) & 1 & $2.439 * * *$ & & 1 & $520.08 *$ \\
Y $\times$ D & 2 & 0.002 & & 1 & 0.33 \\
T $\times$ D & 2 & $0.447 * * *$ & 2 & 36.02 \\
Y $\times$ T $\times$ D & 4 & 0.009 & & 2 & 17.27 \\
Error C & 27 & 0.017 & 18 & 117.17 \\
\hline
\end{tabular}

a Tillage treatments were no-tillage, disk-tillage, and moldboard plow. Soil depths were 0 to 7.5 and 7.5 to $15 \mathrm{~cm}$.

${ }^{\mathrm{b}}$ Significance levels: *, $P=0.05$; **, $P=0.001$; and $* * *, P=0.0001$.

Table 2. Tillage and soil depth effects on soil population density of Macrophomina phaseolina, CFU/gram of dry soil, averaged over years ${ }^{\mathrm{a}}$

\begin{tabular}{lccc}
\hline & \multicolumn{3}{c}{ Tillage } \\
\cline { 2 - 4 } Depth & No-tillage & Disk-tillage & Moldboard plow \\
\hline 0.0 to $7.5 \mathrm{~cm}$ & 99.58 & 78.33 & 61.38 \\
7.5 to $15 \mathrm{~cm}$ & 22.99 & 31.98 & 50.92 \\
$\mathrm{LSD}_{(0.05)}$ depth means for same tillage $=13.50$ & & \\
LSD $_{(0.05)}$ across tillage same or different depth $=13.12$ & & \\
\hline
\end{tabular}

a Years were 1992, 1993, and 1994. tion sites on roots from 0 to $7.5 \mathrm{~cm}$ or 7.5 to $15 \mathrm{~cm}$ deep in the soil, respectively.

Late season colonization of soybean roots by $M$. phaseolina was investigated during 1992 to 1994. Six plants, growth stage R7 (2), were removed from the outside two rows of each plot. Roots were washed to remove soil, and $121.0-\mathrm{cm}$ root segments per intact root system were arbitrarily selected. Root segments were surface disinfested in $0.5 \%$ sodium hypochlorite for $1 \mathrm{~min}$, rinsed in distilled water for $10 \mathrm{~s}$, and plated on CMRB agar. Root segments were not separated by soil depth because the mass of roots on these plants made differentiation by soil depth very difficult. After 2 to 3 days at $32^{\circ} \mathrm{C}$, the number of root segments colonized by $M$. phaseolina was determined. The percentage of the $12 \mathrm{seg}$ ments from which $M$. phaseolina was isolated was used in the analysis.

The organic matter content of each soil sample collected in 1993 was determined using the Walkly-Black method (9).

ANOVA was used to analyze all data, and mean separation was by an $F$ test protected LSD (5). SAS (SAS Institute, Cary, NC) was used for all analyses. Data were pooled where appropriate for analysis of means over years.

\section{RESULTS}

Analysis of variance for soil population density of $M$. phaseolina data collected in 1992 to 1994 indicated that year and soil depth effects were significant (Table 1). The overall population density was significantly lower $(P=0.05)$ in 1994 (45 CFU/g soil) than in 1992 (61 CFU/g soil) and 1993 (67 CFU/g soil). Significant interactions were observed between tillage and soil depth (Table 1). When averaged over years, the soil population density of $M$. phaseolina was significantly greater within the 0 - to $7.5-\mathrm{cm}$ than the $7.5-$ to $15-\mathrm{cm}$ soil depth for no-tillage and disk-tillage plots (Table 2). The population densities in plowed soil were similar between the two soil depths. The population density was significantly greater in the $0-$ to $7.5-\mathrm{cm}$ layer of soil in no-tillage than in disk-tillage plots and lowest in moldboard plow plots. There were no significant differences in population density in the $7.5-$ to $15-\mathrm{cm}$ layer between no-tillage and disk-tillage.

Analysis of variance for the number of sites infected on V6 growth stage plant roots collected in 1993 and 1994 indicated that year and soil depth effects were significant (Table 1). The number of early season infection sites per 10 plants over soil depths was significantly greater $(P=$ 0.001 ) in 1993 (74 infection sites) than in 1994 (44 sites) and significantly greater over years $(P=0.05)$ in the 0 - to $7.5-\mathrm{cm}$ (62 sites) than the 7.5- to $15-\mathrm{cm}$ (56 sites) soil layer. Tillage, however, did not affect the number of sites infected.

Analysis of variance for the percentage of R7 growth stage plant root segments 
colonized by M. phaseolina during 1992 to 1994 indicated that only year effects were significant (Table 3). The percentage of R7 growth stage plant root segments colonized by $M$. phaseolina was significantly less $(P$ $=0.007)$ in $1992(74 \%)$ than in either 1993 $(90 \%)$ or $1994(88 \%)$.

Significant interactions $(P=0.0001)$ were observed between tillage and soil depth for soil organic matter (Table 4). Organic matter in disk-tillage and no-tillage soil was significantly greater in the 0to $7.5-\mathrm{cm}$ than the 7.5 - to $15-\mathrm{cm}$ soil depth (Table 5). There were no significant differences in organic matter observed between soil depths in plowed soil, and there were no significant differences in organic matter level in the 7.5- to $15-\mathrm{cm}$ depth among tillage treatments.

There was no significant correlation been organic matter and population density of $M$. phaseolina in the $0-$ to $15-\mathrm{cm}$ soil layer. However, there was a significant and positive correlation $(P=0.0001)$ between organic matter and population density of M. phaseolina in the 0 - to 7.5-cm-deep layer of soil.

Soybean yields were similar between tillage treatments and years (data not shown). The yields averaged $1,998 \mathrm{~kg} / \mathrm{ha}$ over all years and tillage practices.

\section{DISCUSSION}

Aggregation in $M$. phaseolina population density has been observed in some fields $(10,11)$; however, the degree of aggregation decreased after one and two diskings (11). Our data did not indicate

Table 3. Analysis of variance for the percent of R7 stage plant root segments colonized with Macrophomina phaseolina for year and tillage ${ }^{a}$

\begin{tabular}{lcc}
\hline $\begin{array}{l}\text { Source of } \\
\text { variation }\end{array}$ & df & $\begin{array}{c}\text { Mean } \\
\text { square }^{\mathbf{b}}\end{array}$ \\
\hline Year (Y) & 2 & $0.087 *$ \\
Rep & 3 & 0.005 \\
Error A & 6 & 0.01 \\
Tillage (T) & 2 & 0.016 \\
Y $\times$ T & 4 & 0.008 \\
Error B & 18 & 0.005 \\
\hline
\end{tabular}

a Tillages were no-tillage, disk-tillage, and moldboard plow. Years were 1992 to 1994.

b Significance level: *, $P=0.0072$.

Table 4. Analysis of variance for soil organic matter for tillage and soil depth ${ }^{\mathrm{a}}$

\begin{tabular}{lcc}
\hline $\begin{array}{l}\text { Source of } \\
\text { variation }\end{array}$ & df & $\begin{array}{c}\text { Mean } \\
\text { square }^{\mathbf{b}}\end{array}$ \\
\hline Tillage (T) & 2 & $2.648^{*}$ \\
Rep & 3 & 0.678 \\
Error A & 6 & 0.183 \\
Depth (D) & 1 & $21.318^{* *}$ \\
T $\times$ D & 2 & $4.519 * *$ \\
Error B & 9 & 0.059 \\
\hline a Tillages were & no-tillage, disk-tillage, and \\
$\quad$ moldboard plow. Depths were 0 to 7.5 and 7.5 \\
$\quad$ to 15 cm.. \\
b Significance levels: *, $P=0.05$ and **, $P=$ \\
$\quad$ 0.0001.
\end{tabular}

aggregation in $M$. phaseolina population density within individual plots. This may be due to the length of time, 14 years, this test was conducted before soil samples were first collected. The uniformity in $M$. phaseolina population density between inrow and between-row samples of disktillage and moldboard plow plots may be due to tillage distribution of the fungus. The reason for the similarity of $M$. phaseolina population density between in-row and between-row samples in no-tillage plots is not clear. Rows in these plots were planted in the previous years stubble, and the plots had not been tilled for 14 years. Moreover, the area between soybean rows was never planted with soybean, and plots were free of weeds that may have been hosts for M. phaseolina. However, soybean roots growing into the area between rows and the decomposing crop residue that fell between rows during harvest may have been the source of this fungus (16).

This is the first report of variation in $M$. phaseolina soil population density by tillage and soil depth. Rothrock and Hargrove (13) determined that the soil population density of $M$. phaseolina was greater in the 0 - to 15-cm layer of soil in no-tilled than in tilled soil planted with grain sorghum. They did not measure the population density at other soil depths. The population density of Rhizoctonia solani AG 4 was not affected by tillage (13). Differences in population density of fungi between tillage treatments may be more evident if soil samples were collected from various depths.

The greater population density of $M$. no-tillage treatment than in other tillage treatments in our experiment may be due to reduced soil compaction. Analysis indicated that the soil bulk density was lower in no-tillage than in plowed plots at this Jackson site in 1992 and 1993 (18). The soil population density of $M$. phaseolina declined as soil compaction increased in central Missouri (4).

The greater population density of $M$. phaseolina in the 0 - to $7.5-\mathrm{cm}$ layer of soil in no-tillage may be due to the greater concentration of $M$. phaseolina-infested residue on the soil surface in no-tillage than in other treatments. Organic matter content and $M$. phaseolina population density in the 0 - to $7.5-\mathrm{cm}$ soil layer were significantly and positively correlated, and the percentage of organic matter was sigphaseolina in the $0-$ to $7.5-\mathrm{cm}$ layer of the

nificantly greater in the upper layer of soil from no-tillage than from other treatments. The greater percentage of organic matter in the no-tillage treatment than in other treatments was presumably from residue of previous crops, including stems, petioles, leaves, and shallow roots, accumulating in this soil layer. There were no differences in root length by tillage and depth at this site in 1992 and 1993 (18), but root mass and volume were not measured by soil depth.

The significantly greater number of $M$. phaseolina infection sites in V6 growth stage soybean roots during 1993 than during 1994 was probably due to the significantly greater soil population density of this fungus at planting in 1993 than in 1994. However, in this experiment the at planting population density of $M$. phaseolina did not affect the percentage of R7 growth stage soybean roots colonized by this fungus. The soil population density of M. phaseolina was significantly greater in 1992 than in 1994, but the percentage of R7 growth stage soybean roots colonized by this fungus was greater in 1994 than in 1992. Factors other than at planting population density may influence late-season infection of soybean roots by $M$. phaseolina. Soil moisture and temperature may have contributed to differences in infection and colonization rates of roots by $M$. phaseolina among years, but these data were not collected during 1992 to 1994.

No correlation was observed between soybean yield and at planting soil population density of $M$. phaseolina in the upper 0 to $15 \mathrm{~cm}$ of soil. This was probably due to the similarity in soil population of $M$. phaseolina in the $0-$ to $15-\mathrm{cm}$ layer of soil observed among treatments. Although the population density in the 0 - to $7.5-\mathrm{cm}$ layer of soil was significantly different among treatments, there were no differences in the population density in the 0 - to $15-\mathrm{cm}$ layer among treatments. The effect of tillage imposed for short periods, 2 to 4 years, on $M$. phaseolina population density in monoculture soybean is unknown. Tillage treatments had been in place in this study 13 years before data were first collected. Over these 13 years, the population may have increased greatly, declined due to the buildup of antagonistic soil microbes, and then reached equilibrium.

In this study, colonization of soybean roots occurred regardless of tillage system. This suggests that efforts to develop cultivars resistant to charcoal rot must be en-

Table 5. Tillage and soil depth effects on percent soil organic matter after tillage treatments were in place 14 years

\begin{tabular}{lccc}
\hline & \multicolumn{3}{c}{ Tillage } \\
\cline { 2 - 4 } Depth & No-tillage & Disk-tillage & Moldboard plow \\
\hline 0.0 to $7.5 \mathrm{~cm}$ & 1.68 & 1.51 & 0.89 \\
7.5 to $15 \mathrm{~cm}$ & 0.78 & 0.67 & 0.85 \\
LSD depth means for same tillage $=0.159$. & & \\
LSD across tillage same or different depth $=0.295$. & & \\
\hline
\end{tabular}


hanced to protect the U.S. soybean crop from this disease since control strategies and systems for this disease, including the use of tillage, are very limited.

The relationship between soil organic matter levels in no-tillage and in moldboard plow treatments after 14 years of the experiment was similar to the relationship after 4 years (19). The organic matter in the levels of soil studied in the no-tillage plots appears to change little after an initial increase during the first few years the practice is imposed.

\section{ACKNOWLEDGMENTS}

We thank Joyce Elrod for her efforts in this project.

\section{LITERATURE CITED}

1. Edwards, J. H., Thurlow, D. L., and Eason, J. T. 1988. Influence of tillage and crop rotation on yields of corn, soybean, and wheat. Agron. J. 80:76-80.

2. Fehr, W. R., Caviness, C. E., Burwood, D. T., and Pennington, J. S. 1971. Stage of development descriptions for soybeans, Glycine $\max ($ L.) Merr. Crop Sci. 11:929-931.

3. Francl, L. J., Wyllie, T. D., and Rosenbrock, S. M. 1988. Influence of crop rotation on population density of Macrophomina phaseolina in soil infested with Heterodera glycines. Plant Dis. 72:760-764.

4. Gangopadhyay, S., Wyllie, T. D., and Luedders, V. D. 1970. Charcoal rot disease of soybean transmitted by seeds. Plant Dis. Rep. 54:1088-1091.

5. Little, T. M., and Hills, F. J. 1978. Agriculture Experimentation. John Wiley \& Sons, New York.
6. Mangold, G. 1992. CRM acres climb. Soybean Digest 3:40-41.

7. Meyer, W. A., Sinclair, J. B., and Khare, M. N. 1973. Biology of Macrophomina phaseolina in soil studied with selective media. Phytopathology 63:613-620.

8. Mihail, J. D. 1992. Macrophomina. Pages 134-136 in: Methods for Research on Soilborne Phytopathogenic Fungi. L. S. Singleton, J. D. Mihail, and C. M. Rush, eds. American Phytopathological Society, St. Paul, $\mathrm{MN}$.

9. Nelson, D. W., and Sommers, L. E. 1982. Total carbon, organic carbon, and organic matter. Pages 565-577 in: Methods of Soil Analysis. Part 2. A. L. Page, ed. American Society of Agronomy, Madison, WI.

10. Olanya, O. M., and Campbell, C. L. 1988. Effects of tillage on the spatial pattern of microsclerotia of Macrophomina phaseolina. Phytopathology 78:217-221.

11. Pearson, C. A. S., Schwenk, F. W., Crowe, F. J., and Kelley, K. 1984. Colonization of soybean roots by Macrophomina phaseolina. Plant Dis. 68:1086-1088.

12. Ploetz, R. C., Mitchell, D. J., and Gallaher, R. N. 1985. Population dynamics of soilborne fungi in a field multicropped to rye and soybeans under reduced tillage in Florida. Phytopathology 75:1447-1451.

13. Rothrock, C. S., and Hargrove, W. L. 1988. Influence of legume cover crops and conservation tillage on soil populations of selected fungal genera. Can. J. Microbiol. 34:201206.

14. Rothrock, C. S., Phillips, D. V., and Hobbs, T. W. 1988. Effects of cultivar, tillage, and cropping system on infection of soybean by Diaporthe phaseolorum var. caulivora and southern stem canker symptom development. Phytopathology 78:266-270.

15. Short, G. E., Wyllie, T. D., and Ammon, V. D.
1978. Quantitative enumeration of Macrophomina phaseolina in soybean tissues. Phytopathology 68:736-741.

16. Short, G. E., Wyllie, T. D., and Bristow, P. R. 1980. Survival of Macrophomina phaseolina in soil and in residue of soybean. Phytopathology 70:13-17.

17. Tyler, D. D., Chambers, A. Y., and Young, L. D. 1987. No-tillage effects on population dynamics of soybean cyst nematode. Agron. J. 79:799-802.

18. Tyler, D. D., Halfman, W., Denton, H. P., and Tracy, P. W. 1994. Trafficability and rooting depth comparisons between no-till and tilled soybeans. Pages 137-143 in: Proc. 1994 South. Conserv. Tillage Conf. Sustain. Agric., Columbia, SC.

19. Tyler, D. D., Overton, J. R., and Chambers, A. Y. 1983. Tillage effects on soil properties, diseases, cyst nematodes, and soybean yields. J. Soil Water Conserv. 38:374-376.

20. Wrather, J. A., Anderson, S. H., Wollenhaupt, N. C., Anand, S. C., and Kendig, S. R. 1993. Effects of tillage, row width, and cultivar on foliar diseases of double-crop soybean. Plant Dis. 77:1151-1152.

21. Wrather, J. A., Anderson, T. R., Arsyad, D. M., Gai, J., Ploper, L. D., Porta-Puglia, A., Ram, H. H., and Yorinori, J. T. 1997. Soybean disease loss estimates for the top 10 soybean producing countries in 1994. Plant Dis. 81:107-110.

22. Wrather, J. A., Kendig, S. R., Anand, S. C., Niblack, T. L., and Smith, G. S. 1995. Effects of tillage, cultivar, and planting date on percentage of soybean leaves with symptoms of sudden death syndrome. Plant Dis. 79:560562.

23. Wyllie, T. D. 1989. Charcoal rot. Pages 30-32 in: Compendium of Soybean Diseases. 3rd ed. J. B. Sinclair and P. A. Backman, eds. American Phytopathological Society, St. Paul, MN. 